Milenko Stanić

University Sinergija, Bijeljina,

Bosnia and Herzegovina

Tamara Stanić ${ }^{2}$

Faculty of technical sciences, Novi Sad

Miladin Rakić ${ }^{3}$

City of Bijeljina
ORIGINAL SCIENTIFIC ARTICLE doi:10.5937/ekonomika1901025S

Received December, 17, 2018

Accepted: February, 17, 2019

\title{
CONCEPT AND LIMITATIONS OF EXISTING MODELS OF FUNDING LOCAL COMMUNITIES IN REPUBLIKA SRPSKA
}

\begin{abstract}
Local communities represent the level of Government where citizens are given the most important rights and obligations that are in the Constitution and the laws available. The aim of this study is the assessment of the economic position of the local community in the financial system of the Republic of Srpska and, accordingly, opportunities for these communities to support and improve the standard of living of its inhabitants. The analysis conducted in this paper show show significant limitations in this respect. Modification of existing models of funding local communities is essential if we want to strengthen their economic function. That attitude is based the basic hypothesis of this work. The survey is based on a more elementary and secondary methods of social science.
\end{abstract}

Key words: local communities, funding of local communities, external debt, local economic development.

Jel classification:H71, H72,H74

\section{КОНЦЕПТ И ОГРАНИЧЕЊА ПОСТОЈЕЪЕГ МОДЕЛА ФИНАНСИРАЊА ЛОКАЛНИХ ЗАЈЕДНИЦА У РЕПУБЛИЦИ СРПСКОЈ}

\begin{abstract}
Апстракт
Локалне заједнице представљају ниво државне власти у којем грађани остварају најважнија права и обавезе које су им уставом и законима стављена на располагање. Предмет истраживања у овом раду је сагледавање економске позиције локалних заједница у финансијском систему Републике Српске и, сагласно томе, могућности тих заједница да подрже и побољшају животни стандард својих становника. Циљ овог рада је критичка анализа
\end{abstract}

\footnotetext{
${ }^{1}$ mstanic@sinergija.edu.ba

2 tamarica.stanic93@gmail.com

${ }^{3}$ miladin.rakic@gradbijeljina.org
} 
постојећег концепта буиетског система у Републици Српској и давање препорука за његово унапређење, како би локалне заједнище појачале своју економску функиију.Анализе урађене у овом раду показују значајна ограничења у том погледу. Измјенапостојећих модела финансирања локалних заједница је неопходна ако се жели јачати њихова економска функиија.На том ставу је базирана основна хипотеза овог рада. Истраживање је базирано на више основних и посебних метода друштвених наука.

Кьучне ријече: локалне заједнице, финансирање локалних заједнииа, спољни дуг, локални економски развој.

\section{Introduction}

Citizens of the local community to fund local economic development. To create new jobs and improve their living standards. Their requirements and expectations are increasing in terms of weak economic development situation in Republic of Srpska (RS). Implementation of these requirements is possible only with the strong financial position of the local community. The subject of this research is financial position of municipalities and towns in Republic of Srpska's budget system and the possibility of strengthening their economic functions.

Association of Municipalities and Cities of Republic of Srpska (AMCRS) delegated the question of bad position of municipalities and cities in the budget system of the Republic of Srpska a few years ago. Their analysis showed that the income of local communities are falling or stagnant over a longer period of time. Such a trend is present in terms of a constant budget income growth at the entity level. The aim of this work is a critical analysis of the existing concept of budget system in Republic of Srpska and recommendations for its improvement, so that the local communities step up their economic function.

Providing a larger amount of funds from the budget of local communities for investment in capital projects is a precondition of economic strengthening. Municipalities and cities of Republic of Srpska in the long run face the situation of constant growth of budgetary finances for employee salaries and social benefits at the expense of capital investment. Modification of such a system of funding local communities is essential if one wants to change their role, from the dominant social to the dominant development function. That attitude is based the basic hypothesis of this work.

The work consists of four interconnected units. In the first part of the work is represented by the existing concept of financing local community in RS. In the second part of the paper, the changes of total revenues, in several years, which are available to local communities. The factor especially analyzed is the foreign debt of RS and its influence on the movement of income to local communities. In the third part of the paper, analyzed the provisions of local communities for investment and other opportunities that are available to local communities to fund local economic development. On the basis of previous knowledge, in the fourth part of the work, I have been given specific recommendations and conclusions to improve the existing system of funding local communities.

More basic scientific methods used in this study. In particular, we relied on methods: analysis, synthesis, concretisation, abstraction, generalization, induction, 
deduction, comparison. Ageneral scientific method used is statistical and historical comparative method.

\section{Politics of Funding Local Communities in Republic of Srpska}

Local communities in Republic of Srpska are financed on the basis of the various direct and indirect sources of income. Basic, direct, sources of revenue of local selfgovernment are: local taxes (on real estate and other baselines), local taxes (municipal, administrative and other fees), local fees (for usage of construction land, rent and other fees), revenues and disposal of assets (income from rent, interest, sale of assets, etc.), other revenues (from the municipal taxes and fines issued) and other revenues based on law (22. Article 18).

Indirect sources of revenue are divided, by specific percentages, between the Republic's budget and budgets of local communities. These revenues are: revenues from indirect taxes, income taxes, income from fees for changing the purpose of agricultural land, income from lease of land in the ownership of the Republic, revenues from concession fees for use of mineral resources, proceeds from the special fee taken from water, material gain and the funds obtained from the sale of the seized items from the Republican Inspection Administration (21. Article 9).

Table 1. Budget revenues of RS and LSA (local self-administration) (in mill. BAM)

\begin{tabular}{|c|c|c|c|c|c|c|c|c|c|c|c|c|c|c|}
\hline Godina & \multicolumn{2}{|c|}{2011.} & \multicolumn{2}{|c|}{2012.} & \multicolumn{2}{|c|}{2013.} & \multicolumn{2}{|c|}{2014.} & \multicolumn{2}{|c|}{2015.} & \multicolumn{2}{|c|}{2016.} & \multicolumn{2}{|c|}{2017.} \\
\hline $\begin{array}{l}\text { Type of } \\
\text { income }\end{array}$ & $\begin{array}{c}\text { RS } \\
\text { budget }\end{array}$ & $\begin{array}{c}\text { LSA } \\
\text { budget }\end{array}$ & $\begin{array}{c}\text { RS } \\
\text { budget }\end{array}$ & $\begin{array}{c}\text { LSA } \\
\text { budget }\end{array}$ & $\begin{array}{c}\text { RS } \\
\text { budget }\end{array}$ & $\begin{array}{c}\text { LSA } \\
\text { budget }\end{array}$ & $\begin{array}{c}\text { RS } \\
\text { budget }\end{array}$ & $\begin{array}{c}\text { LSA } \\
\text { budget }\end{array}$ & $\begin{array}{c}\text { RS } \\
\text { budget }\end{array}$ & $\begin{array}{c}\text { LSA } \\
\text { budget }\end{array}$ & $\begin{array}{c}\text { RS } \\
\text { budget }\end{array}$ & $\begin{array}{c}\text { LSA } \\
\text { budget }\end{array}$ & $\begin{array}{c}\text { RS } \\
\text { budget }\end{array}$ & $\begin{array}{c}\text { LSA } \\
\text { budget }\end{array}$ \\
\hline $\begin{array}{c}\text { Tax } \\
\text { income }\end{array}$ & 1.389 & 390 & 1.397 & 373 & 1.361 & 342 & 1.372 & 345 & 1.569 & 374 & 2.348 & 381 & 2.476 & 374 \\
\hline $\begin{array}{l}\text { Indirect } \\
\text { taxation }\end{array}$ & 1.044 & 306,6 & 1.048 & 293 & 1.008 & 257 & 1.046 & 268 & 1.129 & 292 & 1.208 & 302 & 1.279 & 290 \\
\hline $\begin{array}{l}\text { Non- } \\
\text { taxative } \\
\text { income }\end{array}$ & 156 & 149 & 158 & 151 & 149 & 156 & 224 & 149 & 230 & 163 & 252 & 174 & 299 & 193 \\
\hline $\begin{array}{c}\text { Total } \\
\text { income }\end{array}$ & 1.544 & 539 & 1.555 & 524 & 1.509 & 499 & 1.596 & 493 & 1.831 & 588 & 2.616 & 607 & 2.804 & 625 \\
\hline
\end{tabular}

Source: Indicative Budget of RS, www.vladars.net

Overview of the revenues of the budget of Republika Srpska, and units of local governments in the RS shows improportional dynamics. Budget revenues of RS have increased from 1,544 million BAM, achieved 2011. year, at 2,804 million BAM, generated in 2017. It is a growth of $182 \%$. In the same period, tax and nontax revenues of local administration grew from 539 million BAM in 625 million BAM, having accomplished an increase of $116 \%$. In this analysis we should bear in mind the fact that, starting from 2016, are in the Republic's Budget included the total contributions to the Pensions Fund. The change in the budget system cannot change the General conclusion about slower growth of budgetary revenue of local authorities in relation to the Budget of RS. 
Figure 1 - growth of total revenues of RS and local self-administrations

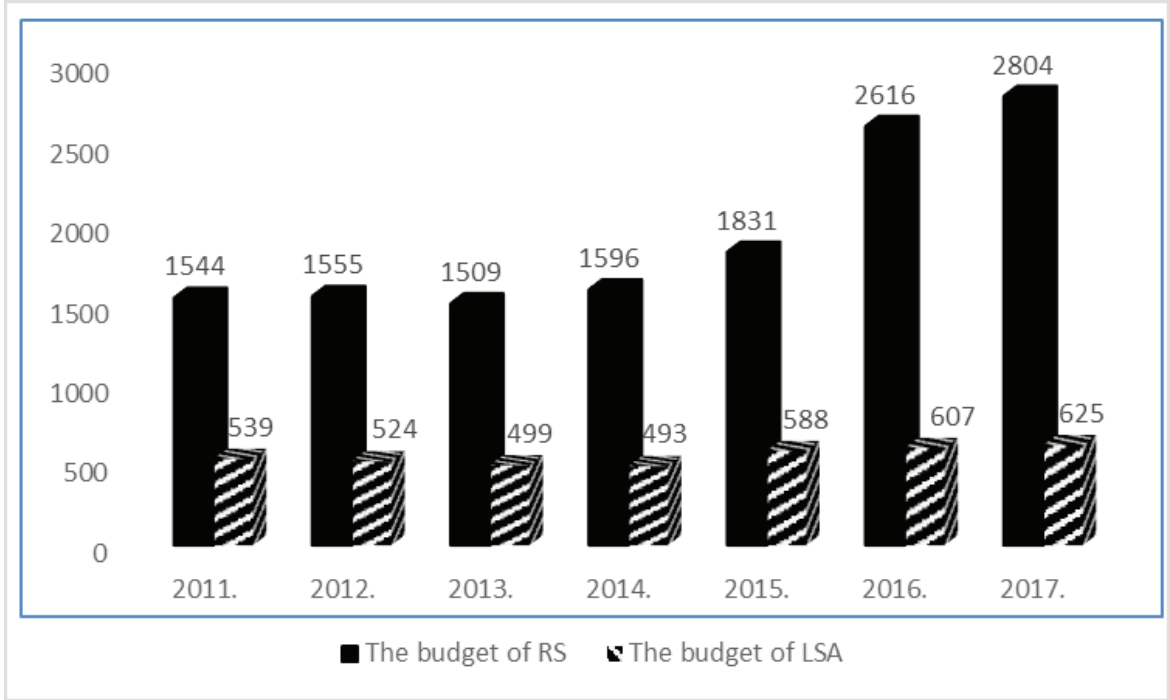

The largest amount of revenue, the Government of Republika Srpska and local communities, are collected on the basis of indirect taxes. Their participation exceeds $70 \%$ of tax revenues on both levels. Allocation of revenues from indirect taxes is done, after the funds from the 2007 budget to pay off the foreign debt, part of which belongs to the RS budget and the part that goes in the distribution to local communities. According to the current law on budget system, the distribution is carried out according to the percentage, for a budget of RS (72.5\%), LSA (24\%) and the public company Roads of RS (3.5\%), (21. Article 9).

Figure 2 - dynamic growth in revenue from indirect taxes RS and LSA

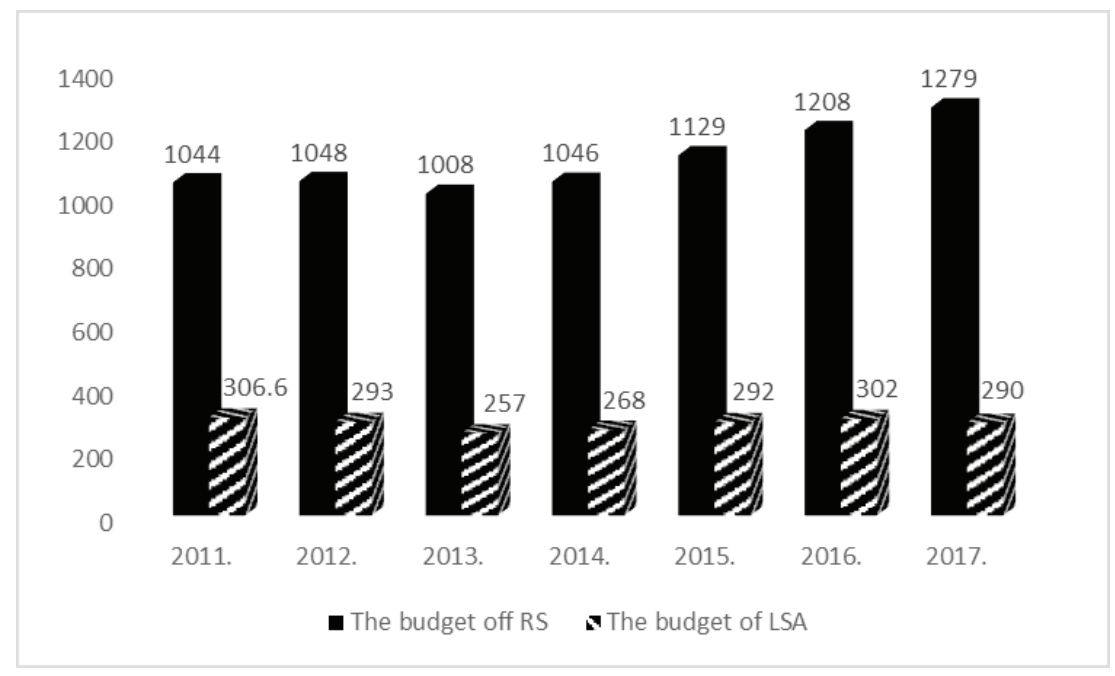


By examining the data from table 1 and figures 2 clearly manifest discrepancy in extracting the resources for the budget and for local self-administrations. In 2011, from these funds for municipalities and cities 306.6 million BAM is planned, and in 2017, 290 million BAMis planned for the main sources of income, indirect taxes, local communities are given less or at best their fundings stagnate. Such trends of income limits the effective functioning of a local communitiy, especially limiting their economic function.

\section{Analysis of the Impact of Republic of Srpska'sExternal Debt Repayment on the Financial Position of Local Self-Administrations}

Reduction of funds recieved by LSA indirect taxes is a result of the growth of foreign debt installment of Republic of Srpska. As this installment is paid, on account in the Central Bank of $\mathrm{BiH}$, out of total assets provided for RS, and the remaining amount is shared between the entity and the local self-administrations, it is clear that greater installment of the external debt has to result in less funding for local self-administrations. Subsequent data confirms this conclusion.

Table 2-distribution of revenues from indirect taxes for the RS (the period from 2011 - 2017. in mill. BAM)

\begin{tabular}{|c|c|c|c|c|c|c|}
\hline Financial year & $\begin{array}{l}\text { The amout of } \\
\text { BAM as an } \\
\text { istallment }\end{array}$ & $\begin{array}{c}\text { RS participation, } \\
\text { before paying } \\
\text { foreign debt } \\
\text { installment }\end{array}$ & $\begin{array}{c}\text { Total participation } \\
\text { of RS, after paying } \\
\text { the installment }\end{array}$ & $\begin{array}{l}\text { LSA participation, } \\
\text { after paying } \\
\text { foreign debt } \\
\text { installment }\end{array}$ & $\begin{array}{c}\text { LSA } \\
\text { participation, } \\
\text { before paying } \\
\text { foreign debt } \\
\text { installment }\end{array}$ & $\begin{array}{c}\text { Difference in LSA } \\
\text { participation }\end{array}$ \\
\hline 1 & 2 & 3 & $4=3+2$ & 5 & 6 & $7=5-6$ \\
\hline 2011 & 124 & 1244 & 1368 & 299 & 328 & -29 \\
\hline 2012 & 169 & 1208 & 1377 & 290 & 330 & -40 \\
\hline 2013 & 238 & 1072 & 1310 & 257 & 314 & -57 \\
\hline 2014 & 242 & 1118 & 1360 & 268 & 327 & -59 \\
\hline 2015 & 204 & 1212 & 1416 & 291 & 340 & -49 \\
\hline 2016 & 257 & 1253 & 1510 & 301 & 362 & -61 \\
\hline 2017 & 348 & 1221 & 1569 & 293 & 377 & -84 \\
\hline Total & 1582 & 8328 & 9910 & 1999 & 2378 & -379 \\
\hline
\end{tabular}

Source: Management of indirect taxation and Ministry of finance

The data presented in table 2 indicate that the installment is constantly growing. In 2007, external debt of 92 million BAM was paid, this amount represents $7 \%$ of the total funds for indirect taxes. 2017, 348 million BAM was paid for the foreign debt, the amount involved with $22 \%$ in funds that belong to the RS of indirect taxes.

The growth of foreign debt is reducing the funding of local self-administrations. Such position of local communities in the budget system of RS is not acceptable. Local communities are paying the debts of the RS Government. This relationship is particularly worrying if you have in mind the document wiht the projections of the framework of the budget of RS which predict further growth of foreign debt in the future. That's projected to be the amount of 351 million BAM in 2018, 298 million BAM in 2019, 271 million BAM in 2020 and 291 million BAM in 2021 (9. p. 37). 
Figure 3 - the dynamics of foreign debt payment by RS and localself-administration revenue from indirect taxation

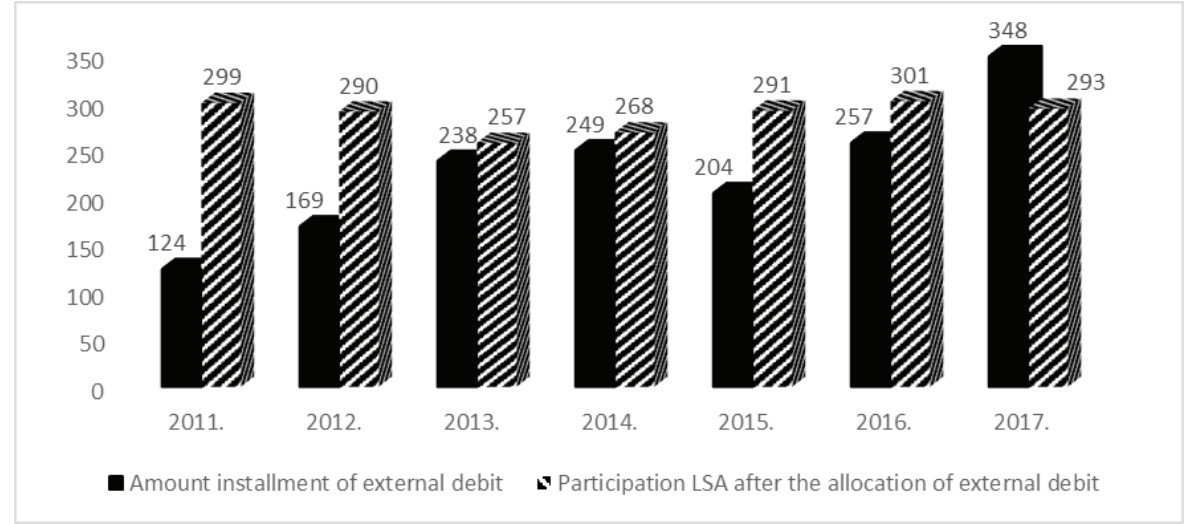

Decrease of the LSA indirect taxes income reflects negatively on their functioning. Many municipalities accumulating unpaid obligations to the employees, local public services and users of welfare. In such conditions it is hard to think about strengthening development functions of local self-administration. Change of the existing system ofindirect tax revenue distribution is necessary if the progress is to be made in this regard. For start it would be enough to reduce the municipality dependance on the amount of RS foreign debt. Introduction of the principle that everyone is paying their debts is acceptable. In this sense, distribution of indirect taxes between RS and local self-administrations should be performed before external debt payment, and then each level of government pays its own debts. Of course, other consequential measures need to be made that would significantly strengthen the position of local communities in the financial system.

\section{Funding a Local Economic Development}

Basically,stimulating a local economic development depends on a proper investment climate in each local environment. Building a competitive advantage for attracting investors is a jobfor each local administration. In this approach we should bear in mind the fact that the limited investment funds (and investors) rivals the large number of local communities. In such a situation, those communities that build „Diamond's“ competitive advantages should expect success. A concept that was created by Michael Porter (Porter, 1990) to measure competitive advantages a state can apply for local communities.

Competitive advantage will be achieved by those local communities that are equipped with: a higher concentration of factors of production (natural factors, human factors, infrastructure, knowledge, culture, tradition, entrepreneurship, good local government and other); greater local and regional markets; supporting industries that willaid the production of competitive products and a stronger competition in the area of production. The previous factors should be noted by the government and other public 
agencies whose policies can support a local development. Success will be achieved by those local communities with the most dynamic process of mutual action of all the aforementioned factors (Stanić M., Stanić T., 2018).

Starting point for local economic development should be determining natural resources at their disposal. It is necessary to list these resources: forests, minerals and mining, land, natural attractions, water and other renewable and non-renewable energy resources. Is necessary to regulate the ownership of these resources and then do a study analyzing their use. The next phase involves the use of these resources to one of the allowed methods: rent, concessions, public-private partnerships, privatization, sales etc.

Local communities should provide additional resources to fund the necessary activities regarding activating natural resources internal redistribution of budgetary expenses and increasing revenue by distributing the fundsin a more just manner between the higher levels of Government and local communities. Local communities do not need to bear the obligation arising from the foreign debt of the entity authorities. Amendments to legislation in this area needs to get more income for local communities from indirect taxes. The existing percentage in the distribution of direct taxes, use of natural resources, should be increased to the benefit of the local communities in which these resources are located.

In planning the development of the local communities it is needed to think about the wider aspect. For many projects it is necessary for more neighbouring local communities to act in accordance. So far, on the territory of RS, there has been no satisfactory cooperation on these issues. The result is that the absence of any regional policy, but is the result and the enclosure of the local administrations that are self-sufficient. Serious tourism development and processing of industrial capacity is not possible without a change in that sphere. The formation of developmental coordinating institutions between the interested municipalities could be an important step forward .

Local development capabilities were largely limited to the general economic situation in $\mathrm{BiH}$ and $\mathrm{RS}$. Authorities could, in a given situation, encourage the development of a region with a number of policy measures that are available to them. That's why it's essential active access to the local administration to the higher levels of Government on these issues. Increased participation in the reallocation of revenue from taxes is one of the ways. An active approach in proposing inclusion of local communities in the important Republic's infrastructure projects is required. From 2015, local communities are involved in the making of public investment plan of RS. In public investment plan of RS for the periodv of 2018-2021, local communities participate with 4 million BAM in the total planned investment for the period of 809 million BAM (18. p. 20).

Certain features in the financing of local development are addressing international development agencies and the use of EU funds. Politics of developing cross-border co-operation, development of renewable energy sources, building a favorable business environment are some of the projects to be financed from EU funds. Public policy in the areas of tourism development, healthy food production, development of small and medium-sized companies have programs that are supported by the development angencies UNDP, USAID, SIDA, GIZ, the Swiss Agency for international cooperation, the EBRD, the World Bank and others.

The creation of a favourable business environment is only a prerequirement for attracting investors and entrepreneurs in the local community. For the successful 
development of the local communities is necessary to attract more investors who will in those communities find the business motivation for investment (profit, growth, synergies with ongoing activities), and at the same time satisfy the needs of local communities ( employment, income growth and public revenue, creating favourable local community identities through a favorable image and reputation).

For the successful development and prosperity of local communities the competitive investors are needed. Investors who are proven in its business in the domestic and international markets. If there is no such, local communities need is to encourage local investors on the merger and joint actions. Such a connection is particularly important for finalising production in many industries. It is undeniable that the current capacity of local investors turn towards lower levels of processing with less technological equipment. Experience that they possess these investors and their capital are a good basis for improving production.

Local communities need not to ignore beginner investors, especially in areas where the local community has the resources for development. Training of the investors in the field of entrepreneurship and businesses starting, financial encouragement for the business start are obligations that stands in front of the administration of all local communities. The development will not happen by itself, nor the market can bring prosperity on its own if an active approach to this issue by local and higher levels of State administration is missed.

Significant potential for investment in each local community exists among our citizens on temporary work abroad. These workers have significant business experience, they have the finances and desire to remain associated with their homeland. All local communities should provide a database of its ex-pats, make connections with them, provide information to each other regularly, and it would be useful to organise ex-pats days in their places of origin . It would be a great chance to hold joint meetings of local investors, local administration representatives and interested investors abroad to get useful ideas about the future development of the local community. Simply, it is needed to modify the qualities of economic contribution of the diaspora, because donations in the future can experience a great fall as family ties and obligations of financing their elders and dependents in their country of origin.

Local communities need to change their attitudes towards investment. The focus on the construction of local infrastructure should move to the construction of industrial plants as generators of progress in this area. These investments can be independent, owned by local communities, but it would be more desirable that it becomes implemented in the form of a public private partnership.

\section{Conclusion}

Financial position of municipalities and towns in Republika Srpska is not satisfactory. Budget revenues for these communities are not enough for high-quality and effective performance of their functions given by the Constitution and laws. In particular, the revenues are not sufficient for the performance of investment activities that are necessary in the current level of economic activity, if it is to meet the expectations of the citizens in terms of growth, employment and living standards. 
The analysis conducted in this paper shows a stagnation in budget revenues in local self-administrations over a longer period of time. This stagnation is caused bythe growth of budget income of the higher levels of Government. Revenues from indirect taxes (VAT, excises, customs), as the most important source of income for alocal selfadministration's budget and the budget of RS, in the analyzed period (from 2011 to 2017) experience a growth. Based on these facts, the problem is not the collection of these revenues, but their fair distribution. Local communities are thus deprived of the parts of the total revenue that they should be given, in accordance to the indirect taxes revenue increase.

The basic problem lies in the fact that the revenues of indirect taxes, which would belong to entities, are firstused torepay the external debt, and only the remaining fundsare shared between the budgets of the local self-administration and the budgets of the entities. As the foreign debt of the RS Government shows significant growth from year to year, it causes reduction of income to local communities in the distribution of the remaining funds from indirect taxes,after having paid foreign debt installment. Local communities in such a way pay the debts of the higher level authorities. Change of such relations is essential.

Introduction of the principle that everyone is paying their own debts is acceptable. In this sense, distribution of indirect taxes revenue between RS and local selfadministrations should be performed before appropriations for external debt, and then each level of government paystheir own debts. In this sense it is necessary to make the appropriate changes to the law on budget system. Of course, that measure should be complemented by several other, that would significantly strengthen the position of local communities in the financial system.

The existing concept of financing of cities and municipalities leaves a large space for their investment activity. The funds for these purposes can increase the internal redistribution to local budgets, cuts other budget outcomes in favor of capital projects, but also make the distribution of tax revenues between entities and local communities more fair. A certain amount of funds can be withdrawn from international development agencies and EU funds.

For the successful development and prosperity of local communities, strategic investors are required. Investors who are proven in their business in the domestic and international markets. If there are no such, local communities need is to encourage local investors to merger and perform joint actions. Significant potential for investment in each local community exists among its citizens on temporary work abroad. These workers have a good business experience, they have the money and desire to remain associated with their home land. Local administrations should constantly take action in the direction of changes to the economic role of the diaspora as the money senders (unilateral transfers) to the leading investors in their home regions.

\section{References}

Domazet, A. (2016). Lokalni ekonomski razvoj i Socijaldemokratska partija BiH, Forum lijeve inicijativa, Sarajevo.

Document the framework of the budget of Republic of Srpska, 2012-2014, www. vladars.net 
Document the framework of the budget of Republicof Srpska, 2013-2015, www. vladars.net

Document the framework of the budget of Republic of Srpska, 2014-2016, www. vladars.net

Document the framework of the budget of Republic of Srpska, 2015-2017, www. vladars.net

Document the framework of the budget of Republic of Srpska, 2016-2018, www. vladars.net

Document the framework of the budget of Republic of Srpska, 2017-2019, www. vladars.net

Document the framework of the budget of Republic of Srpska, 2018-2020, www. vladars.net

Document the framework of the budget of Republic of Srpska, 2019-2021, www. vladars.net

GEA, centar za istraživanja i studije, (2016). Analiza uticaja rastućih obaveza po osnovu spoljnog duga Republike Srpske na prihode gradova i opština, Banja Luka, www.gea.ba

Report of the ITA for the year of 2011, www.uino.gov.ba

Report of the ITA forthe year of 2012, www.uino.gov.ba

Report of the ITA forthe year of 2013, www.uino.gov.ba

Report of the ITA for the year of 2014, www.uino.gov.ba

Report of the ITA for the year of 2015, www.uino.gov.ba

Report of the ITA for the year of 2016, www.uino.gov.ba

Porter, M. (1990). Competitive advantage, Free Press, New York, 1985.

Proposal Of public investment of Republic of Srpska for the period 2018-2020. year, the RS Government, www.vladars.net.

Statistical portal CBBH Necto Panorama http://statistics.cbbh.ba

Stanić, M. Stanić, T. (2018). Politike i instrumenti za finansiranje lokalnog ekonomskog razvoja u Republici Srpskoj, Zbornik radova sa 19. naučnog skupa Sinergija, Univerzitet Sinergija, Bijeljina.

The law on budget system of Republika Srpska, Official Gazette RS, no. 121/2012.

The law on local self-government, Official Gazette RS, no. 97/2016. 